\title{
Critical evaluation of faunistic data: Three species of monotrysian moths (Eriocraniidae, Prodoxidae and Incurvariidae) erroneously reported from Russia
}

\author{
MikHail V. KozLov ${ }^{1}$ \\ 1 Department of Biology, University of Turku, FI-20014Turku, Finland; mikoz@utu.fi \\ http://zoobank.org/A3E3675A-DCC4-4E20-BDDC-CD4E4B72D437
}

Received 2 April 2018; accepted 23 May 2018; published: 27 June 2018

Subject Editor: Jadranka Rota.

\begin{abstract}
The published records of Eriocrania chrysolepidella Zeller, 1851, Incurvaria koerneriella (Zeller, 1839) and Lampronia aeneella (Heinemann, 1870) from Chuvash and Karelia Republics in Russia are based on misidentified specimens. This finding, along with earlier reports on the widespread occurrence of errors, even in the most authoritative works, calls for a critical approach to published data in order to stop spreading and citing false information across future publications.
\end{abstract}

\section{Introduction}

All scientists know that the written word persists. We entomologists routinely use faunistic and natural history data that were published by our colleagues decades and centuries ago. The record of a species in a certain region, or on a certain host plant, causes a cascading effect on subsequent publications, in particular through the checklists and identification keys that summarize these data. Checking old faunistic and host plant records, and especially non-referenced ones, is often impossible, so we have no other option than to trust the authors of earlier publications. However, if the circumstances permit, the 'suspicious' records should indeed be scrutinized.

While updating the distribution records of several moth families for the forthcoming second edition of the Catalogue of the Lepidoptera of Russia (henceforth, the Catalogue; first edition: Sinev 2008), I recognized that Lastukhin $(2001,2007)$ reported three species of monotrysian moths - Eriocrania chrysolepidella Zeller, 1851 (Eriocraniidae), Incurvaria koerneriella (Zeller, 1839) (Incurvariidae) and Lampronia aeneella (Heinemann, 1870) (Prodoxidae) - from Chuvash Republic, located in the centre of European Russia. Lastukhin (2001) stressed that this was the first report of I. koerneriella and L. aeneella from Russia. However, no materials that I have studied to date have contained any specimens of these three species that were collected in Russia, and no other publication indicates their occurrence in Russia. Here, I report the results of re-identification of the moth specimens on which the records of these three monotrysian species from Russia were based. 


\section{Material}

Albert A. Lastukhin (Cheboksary, Russia) kindly sent me the remnants of the moths that he had identified as E. chrysolepidella and I. koerneriella and had deposited in his private collection. The material consists of wings and genitalia preparations glued with transparent tape to a piece of paper (Figs 1-2); the heads, bodies and legs of the moths are absent. This extremely unusual mode of preservation of moth specimens naturally limits the possibility of their identification.

The pinned specimen, which A. A. Lastukhin reported as L. aeneella, was found in the private collection of Vissarion P. Losmanov (Cheboksary, Russia), based on the label information published by Lastukhin (2001). I investigated photographs of this specimen, which were kindly prepared by Leonid Egorov.

\section{Results}

The female moth identified by A. A. Lastukhin as E. chrysolepidella clearly belongs to a heteroneuran family, as can be concluded from its wing shape and from the presence of the single R vein in the hind wings (Fig. 3). The structure of the female genitalia (Fig. 5) narrows the possible identity of this specimen to one of the families of Adeloidea. A species-level identification is not possible, but I tentatively assign this specimen to the genus Lampronia Stephens, 1829. The collection date, wing size and poorly visible wing pattern jointly suggest that this specimen could belong to $L$. corticella (Linnaeus, 1758), which had been reported from the mid-Volga region (Kozlov 2008a).

In the first edition of the Catalogue, E. chrysolepidella was reported from Karelia Republic in Russia (Kozlov and Sinev 2008). Kutenkova et al. (2015) indicated that this record is based on an unknown data source. I revised this record and found that I had included it in the Catalogue based on one specimen labelled "Petrosaw.[odsk]" from the collection of the Zoological Institute in St. Petersburg (ZISP). The identification of this specimen (presumably made by A. K. Zaguljaev) had not been checked by me at that time, but in the course of the subsequent revision of the ZISP collection, the specimen was re-identified as E. semipurpurella (Stephens, 1835). Thus, the record of E. chrysolepidella from Karelia was also based on a misidentification.

The male specimen identified by A. A. Lastukhin as I. koerneriella clearly belongs to the genus Incurvaria Haworth, 1829. However, I. koerneriella has plain wings without a pattern, whereas the forewings of the specimen from the collection of A. A. Lastukhin have clearly visible light spots: one small spot at the costal margin, at about 0.8 of the wing length from its base, and two large triangular spots at the dorsal margin (Fig. 4). These spots are typical for I. oehlmanniella (Hübner, 1796), and the characters of the male genitalia support this identification. I. oehlmanniella was reported earlier from the mid-Volga region (Kozlov 2008b).

The situation with L. aeneella is more complicated, because, as noted by Huemer (2013, p. 205): "the species was described without further details from Austria, its taxonomic status is doubtful, and there exists no type material". Nevertheless, Heinemann (1870) described the forewing colour of $L$. aeneella as greenish and did not indicate the existence of any forewing pattern in this species. Intriguingly, Zaguljaev (1978b) published a drawing of the male genitalia of L. aeneella, but I strongly doubt that this drawing was made from the specimen of L. aeneella sensu Heinemann. Thus, reliable identification of L. aeneella is not possible at the moment. 


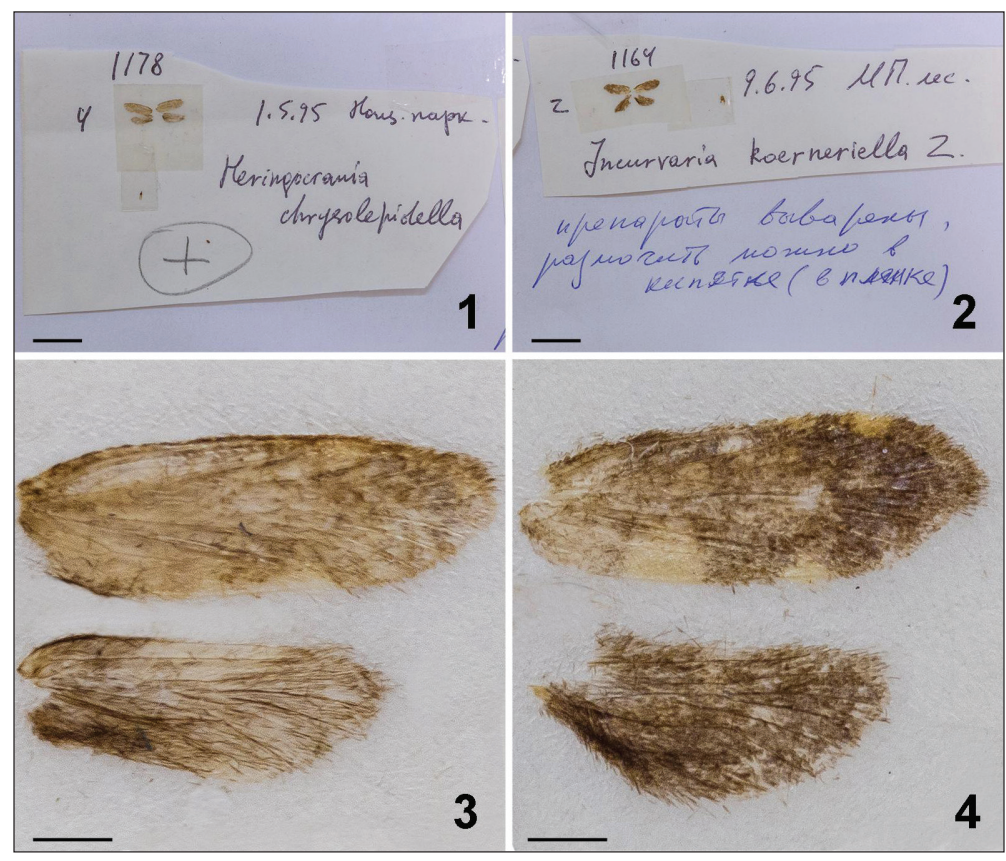

Figures 1-4. The investigated specimens from the private collection of A. A. Lastukhin. 1. Lampronia sp. (misidentified as Eriocrania chrysolepidella), the mode of preservation, scale: $10 \mathrm{~mm}$; 2. Incurvaria oehlmanniella (misidentified as I. koerneriella), the mode of preservation (the text in blue pen: "[Genitalia] preparations are macerated, they could be softened by boiling in water"), scale: $10 \mathrm{~mm} ; \mathbf{3}$. Lampronia sp., wing venation and pattern, scale: $1 \mathrm{~mm}$; 4. I. oehlmanniella, wing venation and pattern, scalebars: $1 \mathrm{~mm}$.

The pinned specimen from Chuvashia, which Lastukhin $(2001,2007)$ reported as L. aeneella, bears an identification label signed by A. A. Lastukhin. This label indicates that the specimen was identified by him as L. rupella (Denis \& Schiffermüller, 1775), and I agree with this identification. The specimen has clearly patterned wings, so that it could not, in any way, belong to the unpatterned L. aeneella. I asked A. A. Lastukhin about the reasons behind the mismatch between the published data and the identification label, and he responded that he had first identified the moth as L. aeneella, but changed his opinion later on.

\section{Discussion}

The proportion of erroneous faunistic records of moths and butterflies, which are scattered across many data sources, may be much larger than is commonly thought. For example, 37 of 733 records of moths and butterflies from the Murmansk Oblast of Russia, which were reported by different authors in the first edition of the Catalogue, were identified as erroneous (Kozlov and Kullberg 2010). Similarly, 30 of 108 species were reported erroneously, or without a proper factual support, from the Nenets Autonomous Okrug and the Novaya Zemlya Region (Kozlov, Kullberg and Zverev, unpublished data). 
The legacy effect of publications containing erroneous data is difficult to overcome. Entomologists are much more motivated to publish new records rather than revise old faunistic data. A search in the Web of Science (all databases) conducted on 16 March 2018 identified 864 publications whose titles mentioned new or first records of some Lepidoptera species or other taxa in some regions. By contrast, only three (!) publications had titles that mentioned corrections of errors in faunistic data published earlier. Nevertheless, some studies publishing new records also report previous misidentifications and correct other errors in the data (e.g. Kozlov and Jalava 1994; Kozlov and Kullberg 2010; Corley 2015).

Regrettably, the published corrections often fail to stop the spread of erroneous data. For example, we explicitly indicated long ago (Kozlov and Jalava 1994) that the records of Nematopogon metaxella (Hübner, 1813) (Adelidae), Agonopterix arctica (Strand, 1902) (Depressariidae) and Elachista poae Stainton, 1855 (Elachistidae) from the Pechenga area in the Murmansk Oblast of Russia (the Petsamo area of Finland at the time of moth collection) published by Valle (1933) are erroneous, or at least doubtful, as they are based on either misidentified or unknown specimens. Nevertheless, the publication by Valle (1933) was uncritically used for preparation of the first edition of the Catalogue, in which these species were reported as occurring in Murmansk Oblast of Russia, so that we were forced to comment on this situation once more (Kozlov and Kullberg 2010).

The long-term persistence of the problematic natural history data in entomological literature can be illustrated by the information on the presumed host plant of Eriocrania argyrolepidella Fuchs, 1904 (the junior subjective synonym of E. cicatricella (Zetterstedt, 1840)). Larvae of all Eriocraniidae species described by the end of the $19^{\text {th }}$ century mined leaves of trees belonging to families Betulaceae and Fagaceae (Meyrick 1912). Nevertheless, the anecdotal observation that the type series of E. argyrolepidella was collected near Populus tremula trees (Fuchs 1904) resulted in an unjustified assumption that larvae of this species are presumably mining the leaves of trembling aspen. This assumption was included in a book by Spuler (1910) and subsequently repeated in many revisions and keys. The most recent studies known to me, which reported E. argyrolepidella as a distinct species presumably feeding on aspen, were published 40 years ago (Davis 1978; Zaguljaev 1978a). In my opinion, this erroneous information on the presumed host plant led to a delay in the clarification of the taxonomic status of E. argyrolepidella.

Clearly, large compiled works, such as checklists or identification keys, will never be completely error-free, so I mention some errors not to criticise the authors but to urge that lepidopterologists take the utmost care to ensure the high quality of the published faunistic and natural history information.

\section{Conclusion}

To date, I am not aware of any reliable records of E. chrysolepidella, I. koerneriella or L. aeneella from Russia, although the first two species occur in Scandinavia and/or in the Baltic countries (Aarvik et al. 2017) and therefore could potentially be found in Russia. The widespread occurrence of errors, even in the most authoritative works, calls for a critical approach to published faunistic and natural history data in order to stop spreading and citing false records across future publications. 


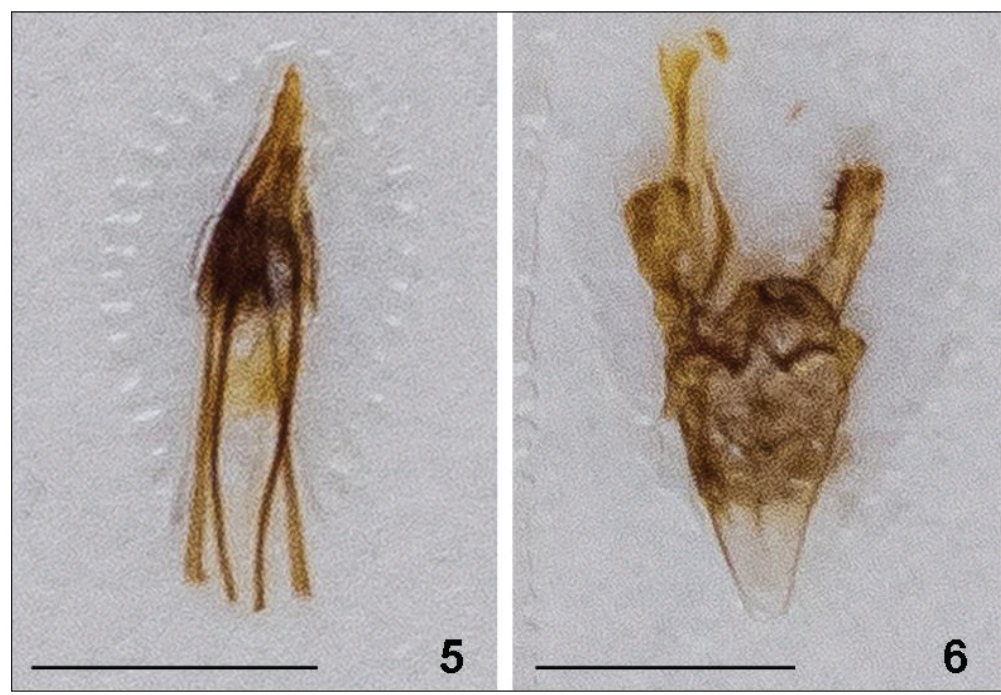

Figures 5-6. Genitalia preparations, as preserved by A. A. Lastukhin. 5. Lampronia sp. (misidentified as Eriocrania chrysolepidella), female, scale: $1 \mathrm{~mm}$; 6. Incurvaria oehlmanniella (misidentified as I. koerneriella), male, scale: $1 \mathrm{~mm}$.

\section{Acknowledgements}

I am grateful to A. A. Lastukhin and V. P. Losmanov for permission to study materials from their private collections, to L. Egorov for logistic support, to V. Zverev for preparation of illustrations, and to L. Egorov, P. Huemer, J. Kullberg, S. Yu. Sinev and E. J. van Nieukerken for commenting the earlier version of the manuscript. The publication was supported by the Societas Europea Lepidopterologica (SEL).

\section{References}

Aarvik L, Bengtsson BÅ, Elven H, Ivinskis P, Jürivete U, Karsholt O, Mutanen M, Savenkov N (2017) Nordic-Baltic checklist of Lepidoptera. Norwegian Journal of Entomology Suppl 3: 1-236.

Corley MFV (2015) The Lepidoptera collections of deceased Portuguese entomologists. II. Entomologist's Gazette 66: 25-49.

Davis DR (1978) A revision of the North American moths of the superfamily Eriocranioidea with the proposal of a new family, Acanthopteroctetidae (Lepidoptera). Smithsonian Contributions to Zoology 251: 1-104. https://doi.org/10.5479/si.00810282.251

Fuchs F (1904) Lepidopterologisches, darunter Beschreibung zweier neuer Arten und einiger abberrativen Falter. Jahrbücher des Nassauischen Vereins für Naturkunde 57: 29-44.

Heinemann H (1870) Die Schmetterlinge Deutschlands und der Schweiz. Zweite Abtheilung. Kleinschmetterlinge. Band II. Die Motten und Federmotten. C. A. Schwetschke und Sohn, Braunschweig, 825 pp.

Huemer P (2013) Die Schmetterlinge Österreichs (Lepidoptera). Systematische und faunistische Checkliste. Studiohefte 12: 1-304.

Kozlov MV (2008a) Prodoxidae. In: Sinev SYu (Ed.) Catalogue of the Lepidoptera of Russia. KMK Scientific Press, Moscow, 26-26. [In Russian] 
Kozlov MV (2008b) Incurvariidae. In: Sinev SYu (Ed.) Catalogue of the Lepidoptera of Russia. KMK Scientific Press, Moscow, 26-27. [In Russian]

Kozlov MV, Jalava J (1994) Lepidoptera of Kola Peninsula, Northwestern Russia. Entomologica Fennica 5: 65-85.

Kozlov MV, Kullberg J (2010) New and interesting records of Lepidoptera from the Kola Peninsula, Northwestern Russia, in 2000-2009. Entomologica Fennica 21: 254-272.

Kozlov MV, Sinev SYu (2008) Eriocraniidae. In: Sinev SYu (Ed.) Catalogue of the Lepidoptera of Russia. KMK Scientific Press, Moscow, 18-18. [In Russian]

Kutenkova NN, Gorbach VV, Polevoi AV, Humala AE (2015) New data from Karelia for the Catalogue of Lepidoptera of Russia. Euroasian Entomological Journal 14(4): 299-308.

Lastukhin AA (2001) The results of investigation of moths and butterflies (Insecta, Lepidoptera) in Chuvash Republic at the turn of the century. Vestnik of Chuvash State Pedagogical University 1(20): 83-91. [In Russian]

Lastukhin AA (2007) Rare moths and butterflies of Chuvash Republic. Ecological Vestnik of Chuvash Republic 59: 1-92. [In Russian]

Meyrick E (1912) Lepidoptera Heterocera: Fam. Micropterygidae. Genera Insectorum 132: 1-9.

Sinev SYu (Ed.) (2008) Catalogue of the Lepidoptera of Russia. KMK Scientific Press, St. Petersburg \& Moscow, 424 pp. [In Russian]

Spuler A (1910) Die Schmetterlinge Europas. II. Bd. des speziellen Teiles. E. Schweizerbart'sche Verlagsbuchhandlung, Stuttgart, $523 \mathrm{pp}$.

Valle KJ (1933) Die Lepidopterenfauna des Petsamogebietes under faunistisch-zoogeographischer Berücksichtigung der Fauna ganz N-Fennoscandias. Annales Zoologici Societatis Zoologicae Botanicae Fennicae "Vanamo" 1: 1-262.

Zaguljaev AK (1978a) Fam. Eriocraniidae - sparkling archaic sun moths. In: Medvedev GS (Ed.) Key for determination of insects of the European Part of the USSR. Vol. IV, Lepidoptera, pt. 1. Nauka, Leningrad, 43-51. [In Russian]

Zaguljaev AK (1978b) Fam. Incurvariidae - leafcutter moths. In: Medvedev GS (Ed.) Key for determination of insects of the European Part of the USSR. Vol. IV, Lepidoptera, pt. 1. Nauka, Leningrad, 75-92. [In Russian] 